\title{
Connective Tissue Graft to Improve Aesthetic Peri-implant Area: Modified Clinical Technique
}

\author{
Jose Kina ${ }^{1 *}$, Eunice Kina ${ }^{2}$, Juliana Kina ${ }^{2}$ and Monica Kina ${ }^{2}$ \\ ${ }^{1}$ Department of Periodontics, Aracatuba School of Dentistry, Sao Paulo State University, Maranhao, Brazil \\ ${ }^{2}$ Private Practice, Araçatuba, Brazil
}

${ }^{*}$ Corresponding author: Jose Ricardo Kina, Professor of Periodontics Department, Aracatuba School of Dentistry, Sao Paulo State University, Maranhao, Brazil, Tel: +55 18 3636-3200; E-mail: kinajr@hotmail.com

Received date: December 13, 2017; Accepted date: January 10, 2018; Published date: January 17, 2018

Copyright: (c) 2018 Kina J, et al. This is an open-access article distributed under the terms of the creative Commons Attribution License, which permits unrestricted use, distribution and reproduction in any medium, provided the original author and source are credited.

Citation: Kina J, Kina E, Kina J, Kina M (2018) Connective Tissue Graft to Improve Aesthetic Peri-implant Area: Modified Clinical Technique. Periodon Prosthodon. Vol.4 No.1:02.

\section{Abstract}

This article reports a clinical case with a 4-years follow-up in which sub epithelial connective tissue graft harvested by two different technique was used to recuperate the aesthetic conditions of the two-previous implanted anterior areas which presented soft tissue fenestration and osseous dehiscence promoted by dental extraction. The highly compromised areas were treated using sub epithelial connective tissue grafts which due the necessity of the quantity and quality were harvested by using two different surgical techniques: dental wedge and free gingival graft. After 4-years of follow-up the goal of treatment was fully reached. The gingival soft tissue around perimplantar area is stable and seems to be normal. The two techniques applied to harvest sub epithelial connective tissue in this case were essential to obtain a large amount of tissue to be grafted. Quality and quantity of the sub epithelial graft are critical conditions to maintain stability during the early phase of healing process, allowing and improving initial revascularization.

Keywords: Aesthetic; Implant; Periodontal surgery; Connective tissue; Case report

\section{Introduction}

Anterior single tooth replacement with a dental implant is challenging, especially in a highly compromised area [1-4]. Anterior areas with bone dehiscence defects promoted by dental extraction may cause aesthetic concerns and functional abnormalities such as gingival recession and dentin hypersensitivity in adjacent teeth [5-7]. When bone dehiscence in anterior area is not recovered by bone augmentation techniques, before dental implant therapy, a critical and complex aesthetic defect may be created [7]. The aesthetic finish of implant/restoration interface always requires healthy peri-implant soft tissue at the adequate location [8-11]. In this case, it was suggested that surgical manipulation/augmentation of peri-implant soft tissue may be beneficial to increase the width/thickness of gingival keratinized tissue and also to improve aesthetic outcomes of implant therapy [12-16]. The sub epithelial connective tissue graft is a gingival plastic surgery that may be used to enhance the aesthetic and gingival contour of the periodontium $[17,18]$. This technique is designed to create gingival keratinized tissue, to recover areas with gingival recession, and also to enhance both the aesthetics and functional periodontal contours surrounding dental implants [17]. Various forms of the connective tissue graft have been used in the aesthetic zone to recover unaesthetic conditions after implant therapy and before definitive crown placement [12-15]. In this clinical case, were applied free gingival graft and distal edge techniques to harvest an adequate amount of sub epithelial connective tissue graft, to recover the functional and aesthetic appearance in two compromised areas, which previously received implant replacement of teeth 12 and 22 . The treatment goal was achieved, and the final outcome resemble, aesthetically and functionally the real teeth surrounded by natural soft tissues.

\section{Case Report}

A patient woman aged 18-year-old, previously received implant replacement of teeth 12 and 22 . The two respective areas presented osseous dehiscence and soft tissue fenestration promoted by dental extraction which induced recession and hypersensitivity in adjacent teeth. Clinical and radiographic evaluation revealed that the pre-existing Osseo integrated fixtures were apically and labially malposition. The soft tissue profiles were deficient, and the resulting gingival margins were $5 \mathrm{~mm}$ apical to the ideal gingival level. The platforms of the fixtures were visible, and considerable black spaces were present in the compromised areas following placement of the provisional restorations (Figure 1). Considerable labial and coronal augmentation were necessary to achieve an aesthetic result. The treatment plan consisted of soft tissue augmentation by using the sub epithelial connective 
tissue graft with technique modification to harvest the connective tissue [19]. The two affected sites were surgically treated by similar procedures, with interval of time around three months. The provisional crowns and abutments were removed from the fixtures, and the internal cover screws were placed in the fixtures. A labial flap was created with splitthickness dissection, and a palatal pouch was made also by split-thickness dissection. A free gingival graft was dissected from the palate and its width was dictated by the site to be augmented and depth of the palatal vault (Figures $\mathbf{2 a}$ and $\mathbf{2 b}$ ). A distal wedge procedure was made at the same side, and the excised connective tissue also was used to improve the augmentation of the compromised area (Figure $\mathbf{2 c}$ ). The epithelial tissue from both, the free gingival graft and excised tissue of the distal wedge procedure were suitable eliminated and then placed over the surgical donor site (Figures $\mathbf{2} \mathbf{b}-\mathbf{2 d}$ ). The connective tissue which was excised by distal edge procedure was placed and fixed on the fixture by a cover screw. The sub epithelial graft harvested from free gingival graft technique was then disposed over the cover screw and inserted into labial and palatal flaps (Figure 3a). The labial and palatal flaps were approximated as much as possible and then sutured to cover the sub epithelial graft (Figures $\mathbf{3 b}$ and $3 \mathrm{c}$ ). The second site was surgically treated by the same technique. The sites were allowed to heal at least for 5 months and were then evaluated to determine if the prosthetic procedures could be defined. After each surgery, bonded restorations were provided with ovate pontic form and placed into prepared sites. After both two areas were recovered with soft tissue, the punch uncovering was performed to uncover the two areas and the convenient healing abutments were placed to keep the areas uncovered. Restorations were initiated 2 weeks later, and the provisional restorations were placed for 2 months to induce healthy and normal gingival shape surround dental implant. After treatment, a rigorous home care routine was established, and the patient was recalled once every six months for professional maintenance care, keeping the treated area under control. After one year the teeth 13 and 21 presented apical lesions and were treated by endodontic treatment (Figure 4). After four years the areas of the implanted teeth 12 and 22 are healthy, with normal aspect, keeping the contour of gingival tissues surround restorations without alterations of the position (Figure 5).

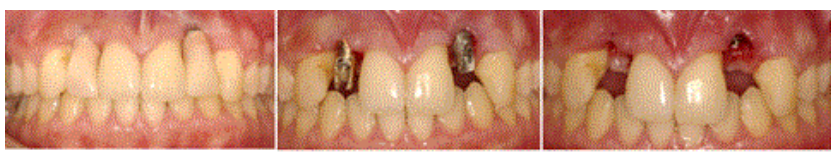

Figure 1 Dental implants apically and labially malpositioned with soft tissue profiles deficient, resulting in gingival margins apical to the ideal gingival level.

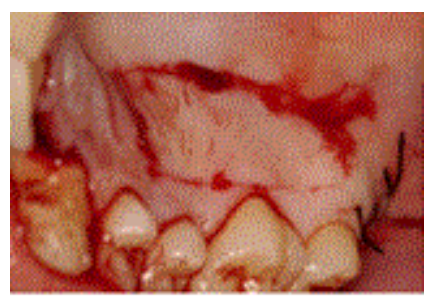

Figure 2a A free gingival graft from the palate.

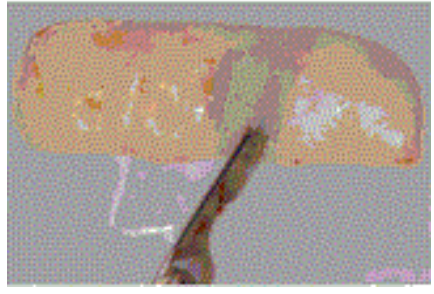

Figure 2b Removing epithelium from free gingival graft by acute dissection.

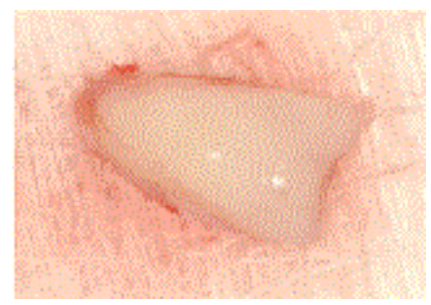

Figure $2 c$ Gingival tissue excised by distal edge procedure.

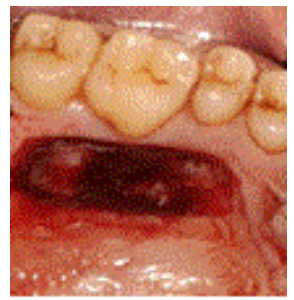

Figure $\mathbf{2 d}$ The epithelial tissue from free gingival graft and excised tissue of the distal wedge procedure placed over the surgical donor site. 


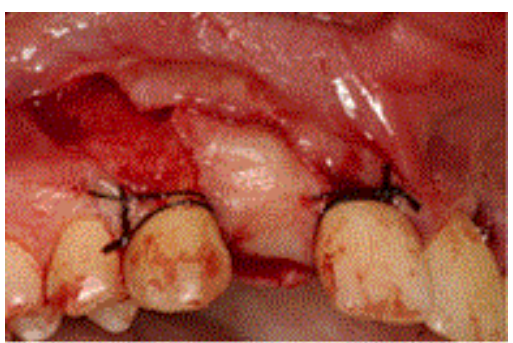

Figure 3a Sub epithelial connective tissue grafts disposed over the cover screw.

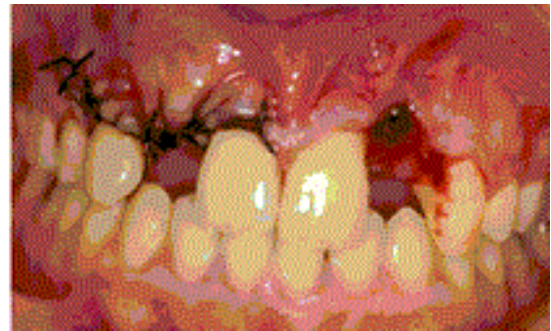

Figure $\mathbf{3 b}$ The surgical areas sutured.

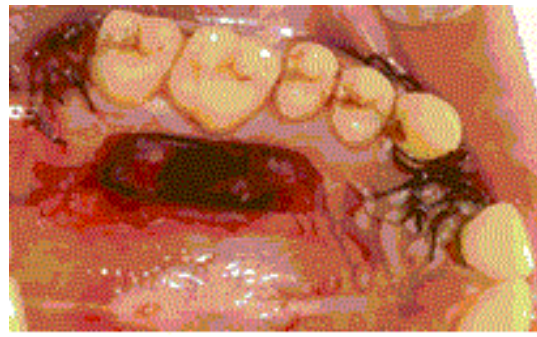

Figure 3c The surgical areas sutured.

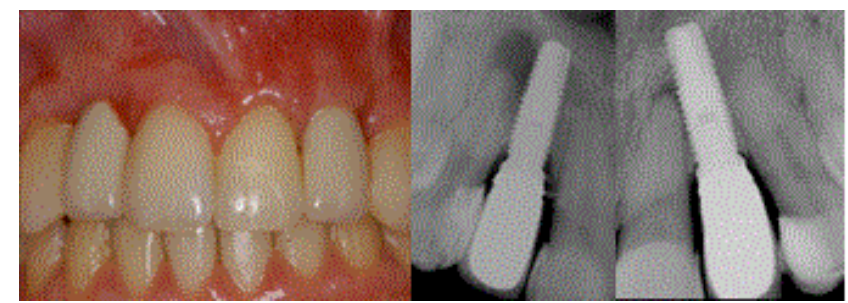

Figure 46 months: clinical and radiographic image (periapical lesions of endodontic origin on teeth 13 and 21).
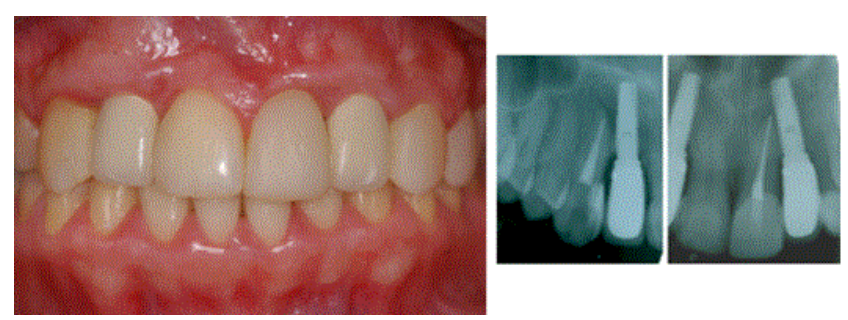

Figure 5 Four year-outcomes after treatment.

\section{Discussion}

Fine aesthetic finish of implant/restorations requires healthy peri-implant soft tissue at appropriate location [10]. A discrepant and abnormal position among implant-restoration, adjacent teeth, peri-implant and periodontal soft tissue may cause unaesthetic appearance [6]. Bone resorption following maxillary anterior tooth extraction is common and often promotes dehiscence defects, which compromises gingival tissue level for the implant restoration $[5,6,10]$. When dehiscence defect was caused by tooth extraction in an anterior area, the presurgical planning should include bone augmentation before implant therapy $[6,20]$. If the affected area is not recovered the fixture may be placed inadequately and the crown restoration will have an undesirable appearance, and the adjacent teeth may present functional abnormalities as gingival recession and dental hypersensitivity $[5,7]$. Although some implant fixture may need to be trephined or retrieved and the site grafted and retreated, these are a long process [12]. One alternative is to attempt soft tissue augmentation around the unaesthetic restoration. The sub epithelial connective tissue graft concept may be useful to augment soft tissue around previously restored implants in an aesthetic zone [13-17]. In this clinical case was applied the distal wedge technique associated with the free gingival graft technique to obtain an adequate quality and quantity of sub epithelial connective tissue graft to recover the compromised areas. The distal edge technique was applied, and the eliminated tissue was dissected to remove its epithelium. An ample free gingival graft was harvested from the palate and its epithelium and a thin layer of connective tissue was dissected and simultaneously with the epithelium eliminated from the distal edge, was placed at the donor site. This procedure permitted to control any risk of heavy bleeding in the donor site which was large and propense for haemorrhagic process and also may facilitate faster healing of the donor site [19] (Figure 4). These two surgical techniques permitted to harvest a significant amount of connective tissue to be used as sub epithelial connective tissue graft, necessary to be grafted at compromised area. The free gingival graft technique, also allowed the possibility to harvest a controlled connective tissue graft, long, wide, thick with a regular amount, and desirable shape. This large and regular connective tissue graft could be placed over the fixture and the connective tissue harvested by distal edge procedure, with its end reaching a minimum of $5 \mathrm{~mm}$ apical to the platform of the implant in 
both sides, which were enveloped into labial and palatal flaps. This procedure was significant to aid mainly the initial stability of the sub epithelial graft allowing the revascularization and maintenance of the amount of connective tissue graft during healing process and also to preserve keratinized gingival in buccal side [21]. Although conventional sub epithelial connective tissue graft may improve the buccal aspect of compromised sites, coronal gains remain unpredictable. The depth and thickness of the palate will affect the possibility to obtain ample amount of the connective tissue without fat and glandular tissue, postoperative sequelae as bleeding and palatal necrosis [19]. The free gingival graft and distal edge techniques may improve harvesting the connective tissue graft in quality and quantity which may permit successful development of vertical soft tissue augmentation with aesthetic appearance and functional peri-implant soft tissue structure. Although scientific evidence in most part is lacking, soft tissue vertical augmentation at implant sites may need to be considered in some clinical situations. After resolving the discrepancy in gingival areas around implants 11 and 21, the challenge became to promote a healthy, normal and adequate aesthetics gingiva surround the prosthetic restoration. The cervical contour of provisional restoration was used to simulate the drawing of the amelocementary junction. This specific design will be responsible by defining the structural shape of the gingival papillae, since the design of the gingival papillae depends intrinsically on the structuring of the biological width surrounding each normal healthy tooth. In normal clinical conditions the biologic width is defined as the junctional epithelium and supracrestal gingival connective tissue attachment surrounding every tooth. The main physiological function of the biologic width seems to be a protective barrier for the subjacent periodontal ligament and the supporting alveolar bone. In a normal healthy dentition, the measurement between the alveolar bone crestal and cementoenamel junction is always almost constant and is occupied by gingival connective tissue attachment surrounding every tooth.

To maintain the measurement of the biological width constant surrounding each normal healthy tooth, the alveolar bone crest follows the design of the cement enamel junction surround each tooth and in consequence marginal gingiva delineates and express similarly the shape of the alveolar bone crest surround each tooth. Thus, the structural shape of the gingival margin by buccal and lingual side seems to be a regular concave arc and the structural shape of the interproximal gingiva called gingival papillae seem to acquire almost the shape of a triangle whose design follows the architecture of the amelocementary junction by mesial and distal sides. These singularities also occur in dental implants with supracrestal gingival connective tissue collagen fibers arranged in the titanium surface parallel to the long axis of the dental implants. Then to restructure the physical shape of the gingival papillae is necessary as part of a strategy with the aim of redrawing the limits of the cement enamel junction and sometimes redraw to reposition the height of the interproximal contact point. Once definition of the gingival contour surrounds the two implants were achieved, a final impression was taken, and the definitive restorations were placed. However, the difficulty in treating this case, emphasize the importance of pre-evaluation of the gingival morphotypes, smiles, and bone architecture previous dental implant placement, to avoid improper implant position with inadequate soft tissue condition.

\section{Conclusion}

Surgical manipulation of peri-implant soft tissue by using techniques to harvest sub epithelial connective tissue graft as applied in this clinical case, may be beneficial to increase gingival keratinized tissue and also to improve aesthetic outcomes of implant therapy.

\section{References}

1. Sugerman PB, Barber MT (2002) Patient selection for endosseous dental implants: oral and systemic considerations. Int J Oral Maxillofac Implants 17: 191-201.

2. Smith RA, Berger R, Dodson TB (1992) Risk factors associated with dental implants in healthy and medically compromised patients. Int J Oral Maxillofac Implants 7: 367-372.

3. Belser UC, Buser D, Hess D, Schmid B, Bernard JP (2000) Aesthetic implant restorations in partially edentulous patients-a critical appraisal. Periodontology 17: 132-150.

4. Schou S, Holmstrup P, Worthington HV, Esposito M (2006) Outcome of implant therapy in patients with previous tooth loss due to periodontitis. Clin Oral Implants Res 17: 104-123.

5. Burkhardt R, Joss A, Lang NP (2008) Soft tissue dehiscence coverage around endosseous implants: a prospective cohort study. Clin Oral Implants Res 19: 451-457.

6. Araujo MG, Lindhe J (2005) Dimensional ridge alterations following tooth extraction. An experimental study in the dog. J Clin Periodontol 32: 212-218.

7. Lost C (1984) Depth of alveolar bone dehiscences in relation to gingival recessions. J Clin Periodontol 11: 583-589.

8. Polimeni G, Koo KT, Qahash M, Xiropaidis AV, Albandar JM, et al. (2004) Prognostic factors for alveolar regeneration: bone formation at teeth and titanium implants. J Clin Periodontol 31: 927-932.

9. Berglundh $\mathrm{T}$, Lindhe $\mathrm{J}$ (1996) Dimension of the periimplant mucosa. J Clin Periodontol 23: 971-973.

10. El Askary AES (2001) Multifaceted aspects of implant esthetics: the anterior maxilla. Implant Dent 10: 182-191.

11. Raigrodski AJ, Block MS (2002) Clinical considerations for enhancing the success of implant-supported restorations in the aesthetic zone with delayed implant placement. Pract Proced Aesthet Dent 14: 21-28.

12. Rapley JW, Mills MP, Wylam J (1992) Soft tissue management during implant maintenance. Int J Periodontics Restorative Dent 12: $373-381$.

13. Silverstein LH, Lefkove MD (1994) The use of the subepithelial connective tissue graft to enhance both the aesthetics and periodontal contours surrounding dental implants. J Oral Implantol 20: 135-138. 
14. Silverstein LH, Kurtzman D, Garnick JJ, Trager PS, Waters PK (1994) Connective tissue grafting for improved implant esthetics: clinical technique. Implant Dent 3: 231-234.

15. Khoury F, Hoppe A (2000) Soft tissue management in oral implantology: a review of surgical techniques for shaping an esthetic and functional peri-implant soft tissue structure. Quintessence Int 31: 483-499.

16. Yeung SCH (2008) Biological basis for soft tissue management in implant dentistry. Aust Dent J 53: 21-28.

17. Langer B, Langer L (1985) Subepithelial connective tissue graft technique for root coverage. J Periodontol 56: 715-720.

18. Martorelli DLA, Silva RC, Joly JC, Tatakis DN (2006) Coronally positioned flap with subepithelial connective tissue graft for root coverage: various indications and flap designs. J Int Acad Periodontol 8: 53-60.
19. Bosco AF, Bosco JMD (2007) An alternative technique to the harvesting of a connective tissue graft from a thin palate: enhanced wound healing. Int J Periodontics Restorative Dent 27: 133-139.

20. Chiapasco M, Zaniboni M (2009) Clinical outcomes of GBR procedures to correct peri-implant dehiscences and fenestrations: a systematic review. Clin Oral Implants Res 20: 113-123.

21. Mörmann W, Schaer F, Firestone AR (1981) The relationship between success of free gingival grafts and transplant thickness revascularization and shrinkage a one-year clinical study. J Periodontol 52: 74-80. 